Prepared in cooperation with the Louisiana Department of Transportation and Development

\title{
Water Resources of Washington Parish, Louisiana
}

\section{Introduction}

Information concerning the availability, use, and quality of water in Washington Parish, Louisiana (fig. 1), is critical for proper water-resource management. The purpose of this fact sheet is to present information that can be used by water managers, parish residents, and others for stewardship of this vital resource. Information on the availability, past and current use, use trends, and water quality from groundwater and surface-water sources in the parish is presented. Previously published reports (see References Cited section) and data stored in the U.S. Geological Survey's National Water Information System (http://waterdata.usgs.gov/nwis) are the primary sources of the information presented here.
In 2010, about 34.55 million gallons per day (Mgal/d) of water were withdrawn in Washington Parish, including about $28.10 \mathrm{Mgal} / \mathrm{d}$ from groundwater sources and $6.44 \mathrm{Mgal} / \mathrm{d}$ from surface-water sources ${ }^{1}$ (table 1). Withdrawals for industrial use accounted for about 52 percent $(17.80 \mathrm{Mgal} / \mathrm{d})$ of the total water withdrawn (table 2). Other categories of use included public supply, rural domestic, irrigation, and livestock. Water-use data collected at 5-year intervals from 1960 to 2010 (fig. 2) indicated that water withdrawals peaked in 1975 at about $51.9 \mathrm{Mgal} / \mathrm{d}$.

${ }^{1}$ Water-withdrawal data are based on estimated or reported site-specific data and aggregated data, which were distributed to sources. For a full description of water-use estimate methodology, see "Data Collection" in Sargent (2011). Tabulation of numbers across text and tables may result in different totals because of rounding; nonrounded numbers were used for calculation of totals.

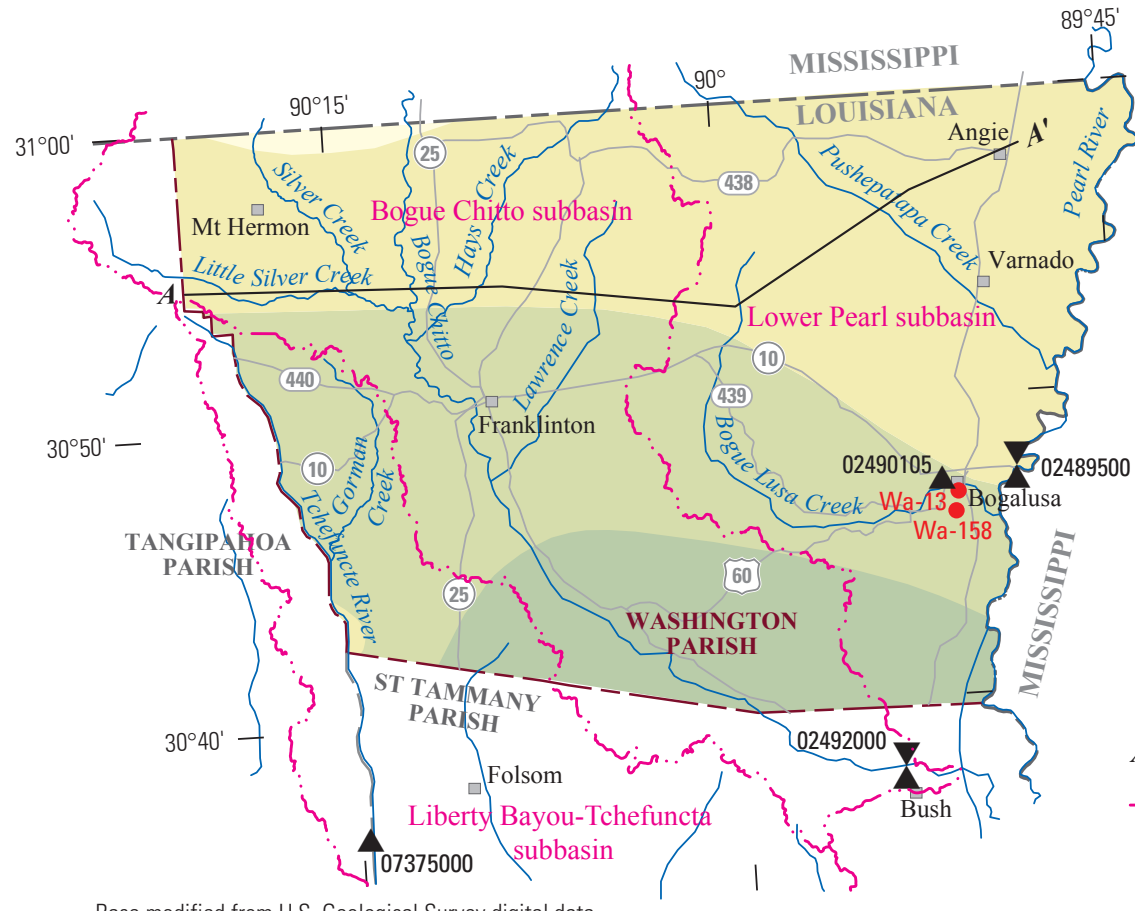

Base modified from U.S. Geological Survey digital data Albers Equal-Area Conic projection North American Datum of 1983

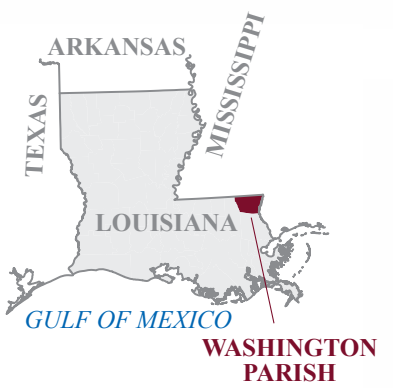

\section{EXPLANATION}

Approximate altitude of base of fresh groundwater, in feet below Nationa Geodetic Vertical Datum of 1929 (modified from Smoot, 1988)-Deepest freshwater contained within the Jasper equivalent aquifer system

Above 2,000

2,000 to 2,499

2,500 to 2,999

3,000 and deeper

$A-A^{\prime} \quad$ Line of section (see fig. 3)

- . - River subbasin boundary

Well for which hydrograph is shown (see fig. 4)

U.S. Geological Survey surface-water discharge site and number

U.S. Geological Survey surface-water quality site and number (see table 4)

Figure 1. Location of study area, Washington Parish, Louisiana. 
Table 1. Water withdrawals, in million gallons per day, by source in Washington Parish, Louisiana, 2010 (Sargent, 2011; B.P. Sargent, U.S. Geological Survey, written commun., 2012).

\begin{tabular}{lcc}
\hline \multicolumn{1}{c}{$\begin{array}{c}\text { Aquifer system or } \\
\text { surface-water body }\end{array}$} & Groundwater & $\begin{array}{c}\text { Surface } \\
\text { water }\end{array}$ \\
\hline $\begin{array}{l}\text { Chicot equivalent aquifer system } \\
\begin{array}{c}\text { Evangeline equivalent } \\
\text { aquifer system }\end{array}\end{array}$ & 6.02 & \\
$\begin{array}{l}\text { Jasper equivalent aquifer system } \\
\text { Bogue Lusa Creek }\end{array}$ & 21.91 & \\
Miscellaneous streams & & 6.18 \\
Total & 28.10 & 0.14 \\
\hline & & \\
\cline { 2 - 3 } & & \\
\hline
\end{tabular}

Table 2. Water withdrawals, in million gallons per day, by use category in Washington Parish, Louisiana, 2010 (Sargent, 2011).

\begin{tabular}{lccr}
\hline \multicolumn{1}{c}{ Use category } & Groundwater & Surface water & Total \\
\hline Public supply & 14.26 & 0.00 & 14.26 \\
Industrial & 11.50 & 6.30 & 17.80 \\
Rural domestic & 1.36 & 0.00 & 1.36 \\
Irrigation & 0.85 & 0.00 & 0.85 \\
Livestock & 0.14 & 0.14 & 0.28 \\
Total & 28.10 & 6.44 & 34.55 \\
\hline
\end{tabular}

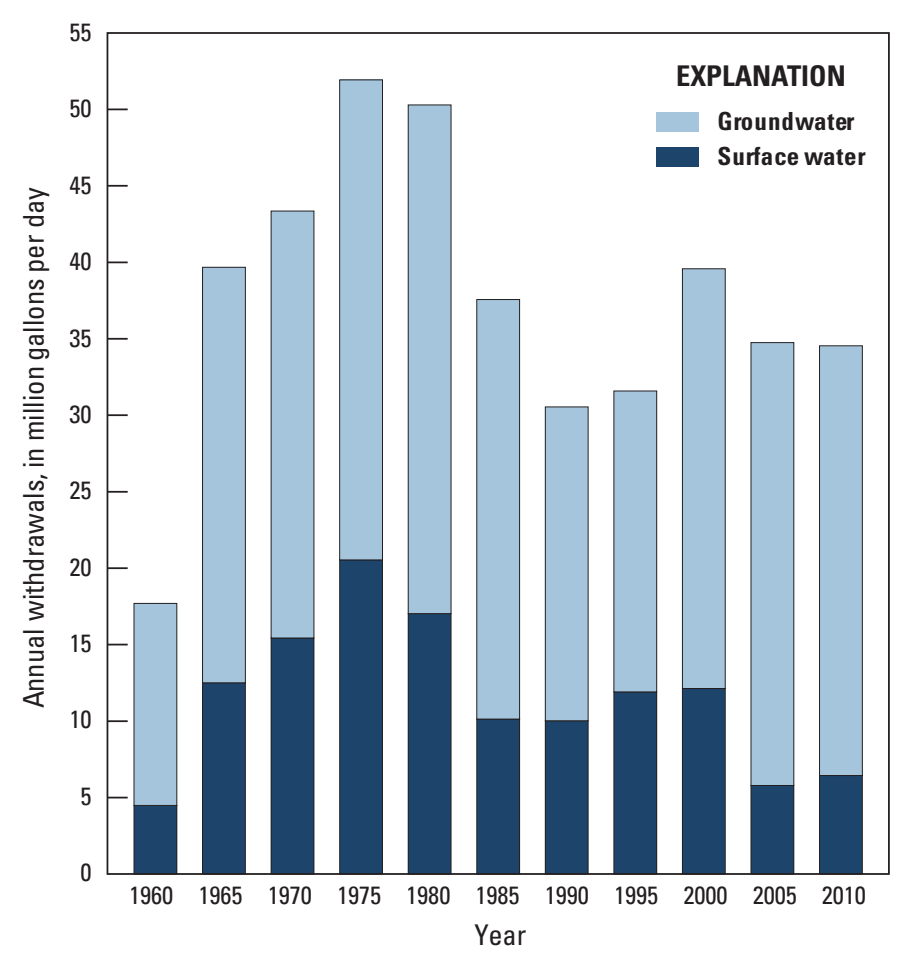

Figure 2. Water withdrawals in Washington Parish, Louisiana, 1960-2010 (Sargent, 2011).

\section{Groundwater Resources}

The primary sources of fresh groundwater (water with a chloride concentration of 250 milligrams per liter $[\mathrm{mg} / \mathrm{L}]$ or less) in Washington Parish are the regional Chicot, Evangeline, and Jasper equivalent aquifer systems (fig. 3). Deeper aquifers in the parish contain saltwater. The base of fresh groundwater is deepest along the southern parish line and shallowest along the northern parish line (fig. 1). Recharge to these aquifer systems is primarily by infiltration of precipitation in a large area extending from within Washington Parish to about 85 miles (mi) north of the Louisiana-Mississippi State line (Griffith, 2003). Discharge from these aquifer systems results from well pumping, interaquifer flow, and flow into surface-water bodies.

\section{Chicot Equivalent Aquifer System}

The Upland terrace aquifer is the only aquifer within the Chicot equivalent aquifer system that is present in Washington Parish. The Upland terrace aquifer is broad and near surface and crops out along ridges and alongside stream valleys. Grain size in the Upland terrace aquifer typically ranges from fine sand to pea gravel. The aquifer dips to the south and extends westward into Tangipahoa Parish and eastward and northward into Mississippi where it correlates with the Citronelle Formation (Nyman and Fayard, 1978). As the Upland terrace aquifer continues dipping to the south into St. Tammany Parish (fig. 1), it merges into and becomes the upper Ponchatoula aquifer (Griffith, 2003). The base of the aquifer system is about 100 feet (ft) above the National Geodetic Vertical Datum of 1929 (NGVD 29) at the north end of Washington Parish and greater than $300 \mathrm{ft}$ below NGVD 29 at the southeastern parish boundary, and thickness generally ranges from about 100 to over $250 \mathrm{ft}$ (Case, 1979; Tomaszewski, 2011).

In 2009, water levels in the Chicot equivalent aquifer system in Washington Parish ranged from a low of about $25 \mathrm{ft}$ above NGVD 29 in the extreme southeastern corner of the parish to a high of over $250 \mathrm{ft}$ above NGVD 29 in north-central and northwestern areas of the parish (Tomaszewski, 2011). The general direction of groundwater flow in the Chicot equivalent aquifer system was southward, with localized flow direction towards the Bogue Chitto and Pearl and Tchefuncte Rivers (fig. 1). In Washington Parish, the water-level surface generally follows the topography (Tomaszewski, 2011). The water level in the Chicot equivalent aquifer system at well Wa-13, located in eastern Washington Parish (fig. 1), has generally fluctuated about $3 \mathrm{ft}$ or less annually (fig. 4).

State well-registration records listed 2,695 active water wells screened in the Chicot equivalent aquifer system in Washington Parish in 2015, including 2,472 domestic, 136 irrigation, 79 public supply, and 8 industrial. Depths of these wells ranged from 20 to $470 \mathrm{ft}$ below land surface, and reported yields have ranged from 8 to 2,000 gallons per minute (gal/min) (Louisiana Department of Natural Resources, 2015). In 2010, withdrawals from the Upland terrace aquifer in Washington Parish totaled about 6.02 Mgal/d (table 1) and included less than $0.01 \mathrm{Mgal} / \mathrm{d}$ for public supply, $0.85 \mathrm{Mgal} / \mathrm{d}$ for irrigation, $3.80 \mathrm{Mgal} / \mathrm{d}$ for industrial use, $1.30 \mathrm{Mgal} / \mathrm{d}$ for rural-domestic use, and $0.07 \mathrm{Mgal} / \mathrm{d}$ for livestock (B.P. Sargent, U.S. Geological Survey, written commun., 2012). 


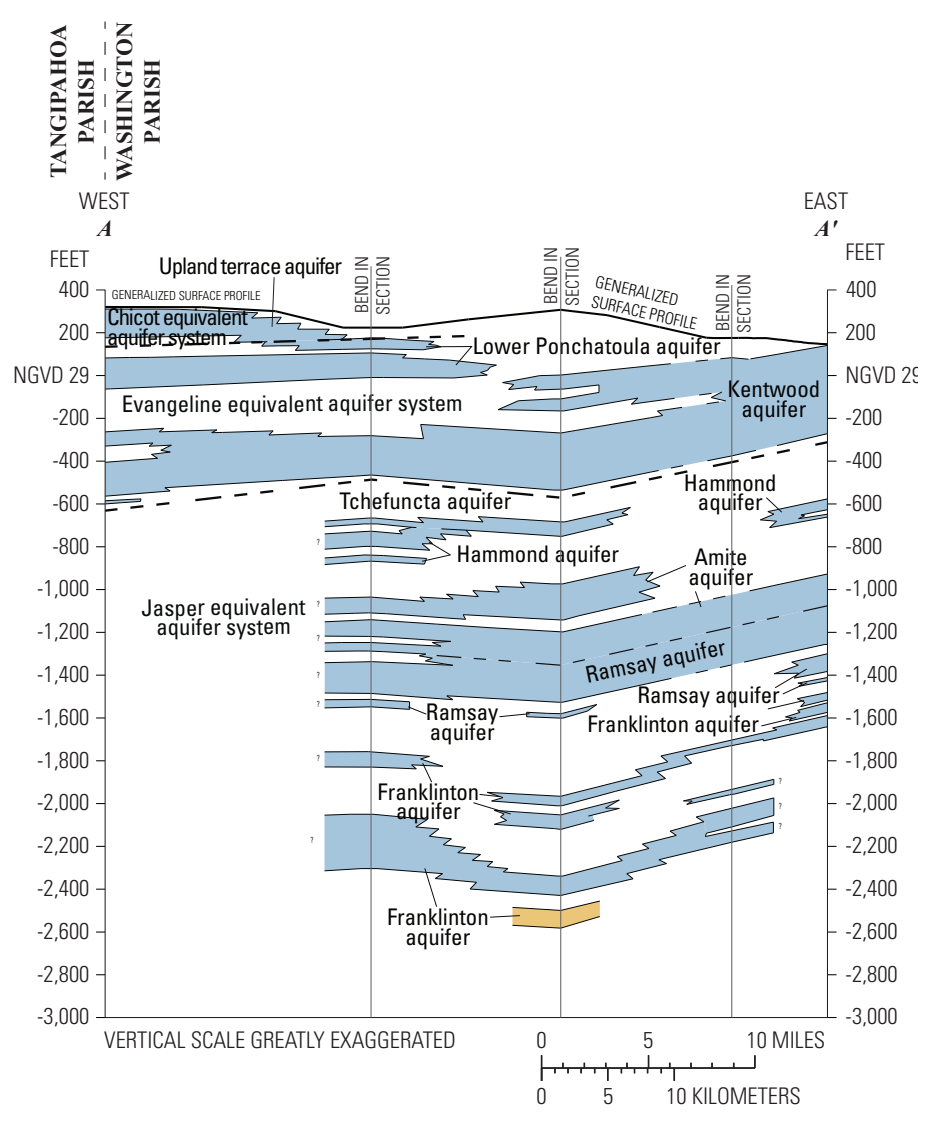

EXPLANATION

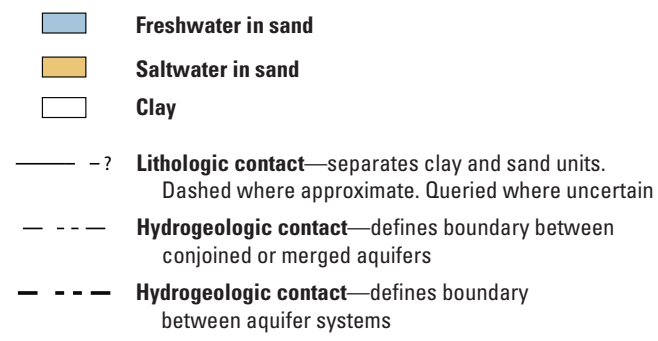

Figure 3. Generalized west-to-east hydrogeologic section through Washington Parish, Louisiana (modified from Griffith, 2003). Trace of section shown on figure 1.

\section{Evangeline Equivalent Aquifer System}

The Lower Ponchatoula, Big Branch, Kentwood, Abita, and Covington aquifers compose the Evangeline equivalent aquifer system in Washington Parish. As the Kentwood aquifer extends southward, it divides into the Abita and Covington aquifers near Bogalusa. Grain size in the Evangeline equivalent aquifer system ranges from sand to very coarse sand. Layers of clay usually separate the individual aquifers (Griffith, 2003). In Washington Parish, the Evangeline equivalent aquifer system dips and thickens in a southerly direction towards the Gulf of Mexico. The altitude of the base of the aquifer system ranges from less than $300 \mathrm{ft}$ below NGVD 29 in northern Washington Parish to over $900 \mathrm{ft}$ below NGVD 29 near the southern parish line (Griffith, 2003). In 2003, water levels in the Kentwood aquifer ranged from about $225 \mathrm{ft}$ above NGVD 29 in the northwestern corner of the parish to about $95 \mathrm{ft}$ above NGVD 29 in the extreme southeastern corner of the parish. The direction of groundwater flow in the Kentwood aquifer was generally to the southeast (Prakken, 2004).
State well-registration records listed 108 active water wells screened in the Evangeline equivalent aquifer system in Washington Parish in 2015, including 84 domestic, 12 irrigation, 7 public supply, 4 industrial, and 1 power generation. Depths of these wells ranged from 150 to $1,047 \mathrm{ft}$ below land surface, and reported yields have ranged from about 1 to 1,650 gal/min (Louisiana Department of Natural Resources, 2015). In 2010, withdrawals from the Evangeline equivalent aquifer system in Washington Parish totaled about $0.18 \mathrm{Mgal} / \mathrm{d}$ (table 1) and included about $0.05 \mathrm{Mgal} / \mathrm{d}$ for public supply, $0.05 \mathrm{Mgal} / \mathrm{d}$ for rural-domestic use, and $0.07 \mathrm{Mgal} / \mathrm{d}$ for livestock (B.P. Sargent, U.S. Geological Survey, written commun., 2012).

\section{Jasper Equivalent Aquifer System}

The Jasper equivalent aquifer system in Washington Parish comprises the Tchefuncta, Hammond, Amite, Ramsay, and Franklinton aquifers (fig. 3). These aquifers are generally composed of fine to coarse sand and generally contain freshwater. The base of freshwater in the parish (fig. 1) generally corresponds to the base of the Franklinton aquifer, except where the aquifer contains saltwater (Nyman and Fayard, 1978). Layers of clay usually separate the individual aquifers; however, some aquifers merge with overlying and underlying aquifers (Nyman and Fayard, 1978; Griffith, 2003). The aquifer system dips and thickens in a southerly direction towards the Gulf of Mexico. The altitude of the base of the aquifer system is not well defined, but geophysical log data indicated that it is less than 2,300 ft below NGVD 29 in northern Washington Parish and deeper than about 3,000 ft below NGVD 29 near the southern parish line (Nyman and Fayard, 1978; Griffith, 2003). In 2006, the general direction of flow in the Amite aquifer in Washington Parish was towards a withdrawal center at Bogalusa, and water levels ranged from about $100 \mathrm{ft}$ above NGVD 29 in the central part of the parish to about the NGVD 29 in Bogalusa (Fendick, 2007). Water levels at well Wa-158, located in eastern Washington Parish (fig. 1) and screened in the Amite aquifer, have fluctuated as much as $50 \mathrm{ft}$ annually because of groundwater withdrawals at Bogalusa (fig. 4).

State well-registration records listed 38 active water wells screened in the Jasper equivalent aquifer system in Washington Parish in 2015, including 23 public supply, 7 domestic, and 8 industrial. Depths of these wells ranged from 750 to $2,752 \mathrm{ft}$ below land surface, and reported yields have ranged from about 20 to 2,900 gal/min (Louisiana Department of Natural Resources, 2015). In 2010, withdrawals from the Jasper equivalent aquifer system in Washington Parish totaled about $21.91 \mathrm{Mgal} / \mathrm{d}$ (table 1) and included about 14.20 Mgal/d for public supply and $7.70 \mathrm{Mgal} / \mathrm{d}$ for industrial use (B.P. Sargent, U.S. Geological Survey, written commun., 2012).

\section{Groundwater Quality}

Water-sample analysis indicated that freshwater from the aquifer systems described above is generally soft, ${ }^{2}$ and median values were below $15 \mathrm{mg} / \mathrm{L}$ for chloride and below $175 \mathrm{mg} / \mathrm{L}$ for dissolved solids (table 3). Median values for temperature and color generally increase with increasing aquifer depth. Locally, concentrations of iron and manganese can greatly

\footnotetext{
${ }^{2}$ Hardness ranges, expressed as milligrams per liter of calcium carbonate, are as follows: 0-60, soft; 61-120, moderately hard; 121-180, hard; greater than 180, very hard (Hem, 1985).
} 


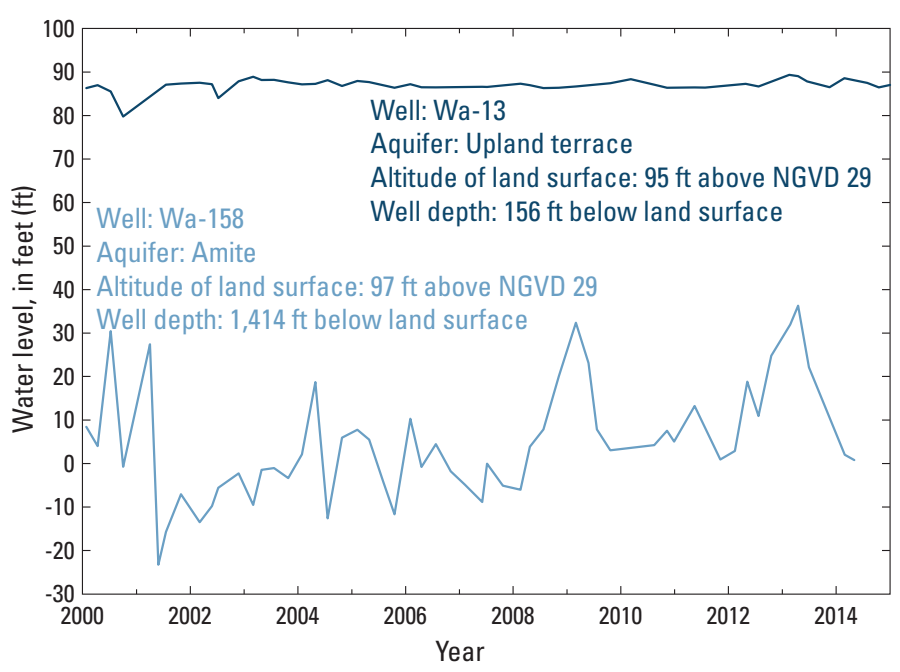

Figure 4. Water levels in well Wa-13 screened in the Upland terrace aquifer and well Wa-158 screened in the Amite aquifer in Washington Parish, Louisiana (see fig. 1 for well locations; U.S. Geological Survey, 2015a). Altitudes of land surface and water level are measured in feet $(\mathrm{ft})$ relative to the National Geodetic Vertical Datum of 1929 (NGVD 29).

exceed the U.S. Environmental Protection Agency's Secondary Maximum Contaminant Levels (SMCLs). ${ }^{3}$ Generally, water samples taken from the Chicot and Evangeline equivalent aquifer systems were found to be slightly acidic, with median $\mathrm{pH}$ values below the lower SMCL of 6.5, whereas samples from the Jasper equivalent aquifer system yielded median $\mathrm{pH}$ values within the SMCL range of 6.5-8.5 standard units (table 3; U.S. Geological Survey, 2015d). A statistical summary of water-quality samples taken from the Chicot, Evangeline, and Jasper equivalent aquifer systems in Washington Parish is presented in table 3.

\section{Surface-Water Resources}

Surface-water resources of Washington Parish are divided into two regional drainage basins. Most of the parish is drained by the Pearl Basin (Hydrologic Unit Code [HUC] 031800), which is divided into the Bogue Chitto subbasin (HUC 03180005) and Lower Pearl subbasin (HUC 03180004) (fig. 1). The southwestern corner of the parish is drained by the Liberty Bayou-Tchefuncta subbasin (HUC 08090201) (fig. 1), which is a part of the Lake Pontchartrain Basin (HUC 080902) (U.S. Geological Survey, 2015c).

\section{Bogue Chitto Subbasin}

The Bogue Chitto subbasin is drained by the Bogue Chitto, which flows southward into Washington Parish from Mississippi and then flows in a southeasterly direction through the parish, eventually flowing into the Pearl River south of the southern parish line. The Bogue Chitto's tributaries include Little Silver Creek, Silver Creek, Hays Creek, Lawrence Creek, and other small streams (fig. 1). The annual average flow of the Bogue

${ }^{3}$ The SMCLs are nonenforceable Federal guidelines regarding cosmetic effects (such as tooth or skin discoloration), aesthetic effects (such as taste, odor, or color), or technical effects (such as damage to water equipment or reduced effectiveness of treatment for other contaminants) of drinking water. SMCLs were established as guidelines by the U.S. Environmental Protection Agency (2016).
Chitto River near Bush (site number 02492000) (fig. 1) was about 1,994 cubic feet per second ( $\left.\mathrm{ft}^{3} / \mathrm{s}\right)$ from 1937 to 2014 from a drainage area of about 1,210 square miles $\left(\mathrm{mi}^{2}\right)$ (U.S. Geological Survey, 2016).

\section{Lower Pearl Subbasin}

The Lower Pearl subbasin is drained by the Pearl River, which flows southward from Mississippi and forms the far eastern border between Louisiana and Mississippi. The Pearl River is fed by Pushepatapa and Bogue Lusa Creeks in Washington Parish and eventually flows into the Gulf of Mexico. The average flow of Bogue Lusa Creek at State Highway 439 at Bogalusa (site number 02490105) was $117 \mathrm{ft}^{3} / \mathrm{s}$ during 1963-85 (Carlson and others, 1985). In 2010, about 6.30 Mgal/d were withdrawn from Bogue Lusa Creek for industrial use (tables 1 and 2). The annual average flow of the Pearl River near Bogalusa (site number 02489500) (fig. 1) was about 9,973 ft's from 1938 to 2014 from a drainage area of about $6,570 \mathrm{mi}^{2}$ (U.S. Geological Survey, 2016).

\section{Liberty Bayou-Tchefuncta Subbasin}

The Liberty Bayou-Tchefuncta subbasin is drained by the Tchefuncte River, which forms part of the boundary between Washington and Tangipahoa Parishes (fig. 1) and is fed by Gorman Creek and other small creeks. Streamflow data are limited for this reach of the river; however, a downstream site on the Tchefuncte River near Folsom (site number 07375000; fig. 1), about $6.5 \mathrm{mi}$ south of the southwestern corner of Washington Parish, recorded an average daily discharge of about $156 \mathrm{ft}^{3} / \mathrm{s}$ during 1943-2014 (U.S. Geological Survey, 2015b).

\section{Surface-Water Quality}

Water samples analyzed during the periods 1962-94 and 1953-95 from the Pearl River and Bogue Chitto, respectively, were found to be soft with respect to hardness and generally did not exceed SMCLs for concentrations of chloride, sulfate, or iron (table 4). The median $\mathrm{pH}$ for both rivers was slightly below the SMCL range of 6.5-8.5 standard units. Dissolved oxygen concentrations for both rivers were generally greater than $5 \mathrm{mg} / \mathrm{L}$, which is considered the minimum value for a diverse population of fresh, warmwater biota, including sport fish (Louisiana Department of Environmental Quality, 2008). A statistical summary of selected water-quality characteristics for the Pearl River and Bogue Chitto is presented in table 4.

\section{References Cited}

Carlson, D.D., Dantin, L.J., Garrison, C.R., and Stuart, C.G., 1985, Water resources data, Louisiana water year 1985: Water-Data Report LA-85-1, 605 p.

Case, H.L., III, 1979, Ground-water resources of Washington Parish, Louisiana: Louisiana Department of Transportation and Development Water Resources Technical Report no. 18, 29 p., 7 pls.

Fendick, R.B., Jr., 2007, Louisiana ground-water map no. 22Generalized potentiometric surface of the Amite aquifer and "2,800foot" sand of the Baton Rouge area in southeastern in Louisiana, June-August 2006: U.S. Geological Survey Scientific Investigations Map 2984, 1 sheet, accessed March 2, 2012, at http://pubs.usgs.gov/ $\operatorname{sim} / 2984 /$. 
Table 3. Summary of selected water-quality characteristics for freshwater in the Chicot, Evangeline, and Jasper equivalent aquifer systems in Washington Parish, Louisiana (U.S. Geological Survey, 2015d).

[Values are in milligrams per liter, except as noted. ${ }^{\circ} \mathrm{C}$, degrees Celsius; $\mathrm{PCU}$, platinum cobalt units; $\mu \mathrm{S} / \mathrm{cm}$, microsiemens per centimeter; SU, standard units; $\mathrm{CaCO}_{3}$, calcium carbonate; $\mu \mathrm{g} / \mathrm{L}$, micrograms per liter; <, less than; SMCL, Secondary Maximum Contaminant Level established by the U.S. Environmental Protection Agency (2016); NA, not applicable]

\begin{tabular}{|c|c|c|c|c|c|c|c|c|c|}
\hline & $\begin{array}{l}\text { Temper- } \\
\text { ature }\left({ }^{\circ} \mathrm{C}\right)\end{array}$ & $\begin{array}{l}\text { Color, } \\
\text { (PCU) }\end{array}$ & $\begin{array}{c}\text { Specific } \\
\text { conduc- } \\
\text { tance, field } \\
(\mu \mathrm{S} / \mathrm{cm} \text { at } \\
\left.25^{\circ} \mathrm{C}\right)\end{array}$ & $\begin{array}{l}\text { pH, } \\
\text { field } \\
\text { (SU) }\end{array}$ & $\begin{array}{l}\text { Hardness } \\
\text { (as } \mathrm{CaCO}_{3} \text { ) }\end{array}$ & $\begin{array}{c}\text { Chloride, } \\
\text { filtered } \\
\text { (as CI) }\end{array}$ & $\begin{array}{c}\text { Iron, } \\
\text { filtered } \\
\text { ( } \mu \mathrm{g} / \mathrm{L} \text { as } \\
\text { Fe) }\end{array}$ & $\begin{array}{c}\text { Man- } \\
\text { ganese, } \\
\text { filtered } \\
\text { ( } \mu \mathrm{g} / \mathrm{L} \text { as } \\
\mathrm{Mn})\end{array}$ & $\begin{array}{l}\text { Dissolved } \\
\text { solids, } \\
\text { filtered }\end{array}$ \\
\hline \multicolumn{10}{|c|}{ Chicot equivalent aquifer system, 1939-2015 (45 wells) } \\
\hline Median & 20.6 & 2.5 & 30.5 & 5.3 & 13 & 11 & $<4$ & $<0.7$ & 115 \\
\hline 10th percentile & 19.7 & 0 & 22.5 & 4.8 & 3.6 & 5.3 & $<4$ & $<0.2$ & 55.8 \\
\hline 90th percentile & 22.3 & 8.5 & 111 & 6.2 & 39 & 25 & $<30.3$ & $<9.3$ & 120 \\
\hline Number of samples & 17 & 4 & 16 & 15 & 21 & 297 & 14 & 14 & 3 \\
\hline $\begin{array}{l}\text { Percentage of samples that } \\
\text { do not exceed SMCLs }\end{array}$ & NA & 100 & NA & 0 & NA & 100 & 93 & 100 & 100 \\
\hline \multicolumn{10}{|c|}{ Evangeline equivalent aquifer system, 1941-89 (29 wells) } \\
\hline Median & 21.2 & 7 & 95 & 6.3 & 16 & 3.1 & 1,300 & 75 & 102 \\
\hline 10th percentile & 20.5 & 0 & 33 & 6.0 & 7 & 2.1 & 30 & 11 & 32 \\
\hline 90th percentile & 24.4 & 20 & 119 & 7.2 & 28 & 4.0 & 2,800 & 200 & 129 \\
\hline Number of samples & 22 & 21 & 23 & 23 & 27 & 29 & 15 & 12 & 20 \\
\hline $\begin{array}{c}\text { Percentage of samples that } \\
\text { do not exceed SMCLs }\end{array}$ & NA & 86 & NA & 43 & NA & 100 & 40 & 33 & 100 \\
\hline \multicolumn{10}{|c|}{ Jasper equivalent aquifer system, 1947-83 (38 wells) } \\
\hline Median & 28 & 10 & 201 & 7.8 & 3 & 3.5 & 490 & 60 & 156 \\
\hline 10th percentile & 23.4 & 0 & 91 & 6.4 & 0 & 2.2 & 50 & 20 & 99.3 \\
\hline 90th percentile & 31.5 & 32.5 & 389 & 8.7 & 11 & 15 & 2,580 & 108 & 248 \\
\hline Number of samples & 50 & 46 & 53 & 51 & 56 & 57 & 37 & 23 & 44 \\
\hline $\begin{array}{c}\text { Percentage of samples that } \\
\text { do not exceed SMCLs }\end{array}$ & NA & 67 & NA & 73 & 100 & 100 & 46 & 48 & 100 \\
\hline \multicolumn{10}{|c|}{ SMCLs } \\
\hline & NA & 15 & NA & $6.5-8.5$ & NA & 250 & 300 & 50 & 500 \\
\hline
\end{tabular}

Griffith, J.M., 2003, Hydrogeologic framework of southeastern Louisiana: Louisiana Department of Transportation and Development Water Resources Technical Report no. 72, 21 p., $18 \mathrm{pls}$.

Hem, J.D., 1985, Study and interpretation of the chemical characteristics of natural water ( $3 d$ ed.): U.S. Geological Survey Water-Supply Paper 2254, 264 p., accessed February 20, 2013, at http://pubs.er.usgs.gov/publication/wsp2254.

Louisiana Department of Environmental Quality, 2008, Environmental Regulatory Code, Title 33, Part IX, Subpart 1: Baton Rouge, Louisiana Department of Environmental Quality, accessed June 9, 2009, at http:www.deq.louisiana.gov/portal/tabid/1674/Default.aspx.

Louisiana Department of Natural Resources, 2015, Strategic Online Natural Resources Information System (SONRIS): Louisiana Department of Natural Resources database, accessed March 3, 2015, at http://sonris.com/.

Nyman, D.J., and Fayard, L.D., 1978, Ground-water resources of Tangipahoa and St. Tammany Parishes, southeastern Louisiana: Louisiana Department of Transportation and Development, Office of Public Works Water Resources Technical Report no. 15, 76 p.
Prakken, L.B., 2004, Louisiana ground-water map no. 17-Generalized potentiometric surface of the Kentwood aquifer system and the "1,500-foot" and "1,700-foot" sands of the Baton Rouge area in southeastern Louisiana, March-April 2003: U.S. Geological Survey Scientific Investigations Map 2862, 2 sheets, accessed February 24, 2012, at http://pubs.er.usgs.gov/publication/sim2862.

Sargent, B.P., 2011, Water use in Louisiana, 2010: Louisiana Department of Transportation and Development Water Resources Special Report no. 17, 133 p.

Smoot, C.W., 1988, Louisiana hydrologic atlas map no. 3-Altitude of the base of freshwater in Louisiana: U.S. Geological Survey Water-Resources Investigations Report 86-4314, 1 sheet, accessed November 2, 2011, at http://pubs.er.usgs.gov/publication/wri864150.

Tomaszewski, D.J., 2011, Water-level surface in the Chicot equivalent aquifer system in southeastern Louisiana, 2009: U.S. Geological Survey Scientific Investigations Map 3173, 2 pls., accessed February 24, 2012, at http://pubs.usgs.gov/sim/3173/.

U.S. Environmental Protection Agency, 2016, Secondary Drinking Water Standards: Guidance for Nuisance Chemicals, accessed April 13, 2016, https:/www.epa.gov/dwstandardsregulations/secondarydrinking-water-standards-guidance-nuisance-chemicals. 
Table 4. Summary of selected water-quality characteristics for the Pearl River near Bogalusa and the Bogue Chitto River near Bush, Louisiana (U.S. Geological Survey, 2015d).

[Values are in milligrams per liter, except as noted. $\mu \mathrm{S} / \mathrm{cm}$, microsiemens per centimeter; ${ }^{\circ} \mathrm{C}$, degrees Celsius; $\mathrm{SU}$, standard units; $\mathrm{CaCO}$, calcium carbonate; $\mu \mathrm{g} / \mathrm{L}$, micrograms per liter; SMCL, Secondary Maximum Contaminant Level established by the U.S. Environmental Protection Agency (2016); NA, not applicable]

\begin{tabular}{|c|c|c|c|c|c|c|c|c|c|c|}
\hline & $\begin{array}{c}\text { Specific } \\
\text { conduc- } \\
\text { tance, } \\
\text { field } \\
(\mu \mathrm{S} / \mathrm{cm} \\
\left.\text { at } 25^{\circ} \mathrm{C}\right)\end{array}$ & $\begin{array}{l}\text { Oxygen, } \\
\text { dissolved }\end{array}$ & $\begin{array}{l}\text { pH, } \\
\text { field } \\
\text { (SU) }\end{array}$ & $\begin{array}{c}\text { Hard- } \\
\text { ness } \\
\text { (as } \\
\mathrm{CaCO}_{3} \text { ) }\end{array}$ & $\begin{array}{l}\text { Calcium, } \\
\text { filtered } \\
\text { (as Ca) }\end{array}$ & $\begin{array}{l}\text { Magne- } \\
\text { sium, } \\
\text { filtered } \\
\text { (as } \mathrm{Mg} \text { ) }\end{array}$ & $\begin{array}{l}\text { Sodium, } \\
\text { filtered } \\
\text { (as Na) }\end{array}$ & $\begin{array}{l}\text { Chloride, } \\
\text { filtered } \\
\text { (as CI) }\end{array}$ & $\begin{array}{l}\text { Sulfate, } \\
\text { filtered } \\
\text { (as } \mathrm{SO}_{4} \text { ) }\end{array}$ & $\begin{array}{c}\text { Iron, } \\
\text { filtered } \\
\text { ( } \mu \mathrm{g} / \mathrm{L} \text { as } \\
\text { Fe) }\end{array}$ \\
\hline \multicolumn{11}{|c|}{ Pearl River near Bogalusa, 1962-941 } \\
\hline Median & 71 & 8.2 & 6.4 & 14 & 3.8 & 1.1 & 6.9 & 7.9 & 8.0 & 200 \\
\hline 10th percentile & 52 & 6.8 & 5.9 & 10 & 2.3 & 0.6 & 4.3 & 4.6 & 4.0 & 90 \\
\hline 90th percentile & 92 & 10.5 & 7.0 & 18 & 5.0 & 1.6 & 11 & 12 & 12 & 360 \\
\hline Number of samples & 366 & 171 & 359 & 334 & 334 & 334 & 331 & 332 & 333 & 86 \\
\hline $\begin{array}{l}\text { Percentage of samples } \\
\text { that do not exceed } \\
\text { SMCLs }\end{array}$ & NA & NA & 41 & NA & NA & NA & NA & 100 & 100 & 83 \\
\hline \multicolumn{11}{|c|}{ Bogue Chitto River near Bush, 1953-95² } \\
\hline Median & 44 & 8.2 & 6.4 & 9 & 2.0 & 0.9 & 4.0 & 6.1 & 2.1 & 200 \\
\hline 10 th percentile & 37 & 7.0 & 5.9 & 7 & 1.6 & 0.5 & 2.7 & 4.1 & 1.0 & 90 \\
\hline 90th percentile & 48 & 10.0 & 6.9 & 10 & 2.7 & 1.1 & 5.1 & 7.6 & 4.3 & 280 \\
\hline Number of samples & 177 & 160 & 188 & 187 & 175 & 175 & 173 & 185 & 181 & 78 \\
\hline $\begin{array}{l}\text { Percentage of samples } \\
\text { that do not exceed } \\
\text { SMCLs }\end{array}$ & NA & NA & 46 & NA & NA & NA & NA & 100 & 100 & 96 \\
\hline \multicolumn{11}{|c|}{ SMCLS } \\
\hline & NA & NA & $6.5-8.5$ & NA & NA & NA & NA & 250 & 250 & 300 \\
\hline \multicolumn{11}{|l|}{${ }^{1}$ Site number 02489500.} \\
\hline${ }^{2}$ Site number 02492000. & & & & & & & & & & \\
\hline
\end{tabular}

U.S. Geological Survey, 2015a, Ground-water levels for Louisiana: National Water Information System Web Interface, accessed November 15, 2015, at http://nwis.waterdata.usgs.gov/la/nwis/ gwlevels.

U.S. Geological Survey, 2015b, National Water Information SystemWeb interface: Accessed March 18, 2015, at http://waterdata.usgs.gov/ nwis.

U.S. Geological Survey, 2015c, Science in your watershed: Accessed May 1, 2015, at http://water.usgs.gov/wsc/.

U.S. Geological Survey, 2015d, Water-quality samples for Louisiana: National Water Information System Web Interface, accessed November 15, 2015, at http://nwis.waterdata.usgs.gov/la/nwis/qwdata/.

U.S. Geological Survey, 2016, Annual water-data reports 2010: USGS Water Resources of the United States, Publications-Annual Water Data Reports, accessed February 5, 2016, at http://wdr.water.usgs.gov/.
This fact sheet was published by the U.S. Geological Survey in cooperation with the Louisiana Department of Transportation and Development (DOTD). Thanks are given to Zahir "Bo" Bolourchi, Director, Water Resources Programs, Louisiana DOTD, who contributed to the content of the fact sheet.

\section{By Vincent E. White and Lawrence B. Prakken}

\section{For additional information, contact:}

Director, USGS Lower Mississippi-Gulf Water Science Center 3535 S. Sherwood Forest Blvd., Suite 120

Baton Rouge, LA 70816

E-mail: gs-w-lmg_center_director@usgs.gov

Fax: (225) 298-5490

Telephone: (225) 298-5481

Home Page: http://la.water.usgs.gov 